\title{
A Review: The Effect of Grinded Coal Bottom Ash on Concrete
}

\author{
Nurul Fasihah Basirun ${ }^{1}$, Mohd Haziman Wan Ibrahim ${ }^{1, *}$, Norwati Jamaludin ${ }^{1}$ and \\ Ramadhansyah Putra Jaya ${ }^{2}$ \\ ${ }^{1}$ Jamilus Research Centre, Universiti Tun Hussein Onn Malaysia, 86400 Parit Raja, Johor, Malaysia \\ ${ }^{2}$ Faculty of Civil Engineering, Universiti Teknologi Malaysia, 81310 Skudai, Johor, Malaysia
}

\begin{abstract}
This paper offers a review on the use of grinded coal bottom ash $(\mathrm{CBA})$ on the concrete properties as demonstrated by strength test and microstructure test. Amount of CBA from power plant station was disposed in landfill because of the particle shape had a rough particles. By finding an alternative way to gain its surface area by grinding and used as replacement material as cement replacement may give a good side feedback on the strength and morphology of concrete. Most of the prior works studied on the grinded fly ash and grinded rice husk ash. The study on the influence of grinded CBA on the properties of concrete still limited and need more attention Therefore, the review on the effect of grinded CBA on the strength and microstructure of concrete are discussed.
\end{abstract}

\section{Introduction}

Concrete is the main choice as building material among all contractors in this world. This is due to concrete is the cheapest than other material and it also can be formed into variety of shapes and sizes. Most of dam, bridge and building all are made by concrete. Burj khalifa is the highest building in this world is one of an example building use concrete as main construction material. It is about 333,000 meters cube concrete is used [1]. As the use of concrete high, the production Portland cements also increase. In 2011, the world production of cement reaches about 3.6 billion tons as the consumption of concrete rises [2]. This is because Portland cement is main ingredients in production concrete and then will mix with sand, water and aggregate [3]. In produce cement powder, the first step are by milling the natural material such as chalk, clay and limestone, then it continues by heating in a kiln. Last part is by uniting it with gypsum [4]. Production for a ton of cement discharged nearly one ton of greenhouse gases, also high emission of $\mathrm{CO}_{2}$ which making it uneconomical process created and high emission of carbon dioxide $\left(\mathrm{CO}_{2}\right)$ and this making it uneconomical [5]. Recently, Malaysia has encouraged the use of "green and recycled by products"[6]. Coal Bottom Ash (CBA) which is the result from the burning of coal is one of those by products. Malaysia has established 4 electrical power stations which composed waste of $80.1 \%$ of fly ash and $19.9 \%$ of CBA [7].Thus, by using coal bottom ash (CBA), it suggested that it can reduce the heat in the atmosphere and carbon dioxide $\left(\mathrm{CO}_{2}\right)$. Besides,

* Corresponding author: haziman@uthm.edu.my 
the uses of recycle product could give an advantage such as in solving environment and economic issues [8]. However, from the literature, it was found that CBA has a large particle size and a porous surface causing in higher water demand and lower compressive strength [9]. Therefore, in order to overcome problem associated with particle shapes of raw CBA, a few researcher made the incorporation of very small size of CBA by increase the surface area [10]. CBA is believed to have good pozzolanic properties if it has high fineness [11]. Previous research reports have investigated on the properties of CBA. However, research studies on the properties of grinded are rarely found. Therefore, the review on the effect of grinded $\mathrm{CBA}$ on the strength and microstructure of concrete are discussed.

\subsection{Coal bottom ash}

Coal is black in color and consists largely of carbon and is made of decomposed plants. According to Pet et al. [12] coal is classified as an organic sedimentary rock. In Malaysia, coal found at 3 geographical provinces in Sarawak, Sabah and Peninsular Malaysia. Coal is transforms electricity by burned in a furnace with a boiler at Power plant. There are four famous electric power plants in peninsular Malaysia that burn the coal namely, Tanjung Bin,Johor (2,100MW), Jimah, Negeri Sembilan (1,400MW), Sultan Salahuddin Abdul Aziz/Kapar, Selangor (2,420 MW) and Sultan Azlan Shah/Mahjung,Perak (2100 MW) power plants[13].

Farhana et al. [13] estimate from 2000 to up to ten years, the use of coal to generate electricity increase by $80 \%$. Fig. 1 shows the system that pictured the process CBA disposed at the bottom [14].According to Abu Bakar et al. [15] in their studied found that the CBA normally found as coarse, porous, light, glassy, granular, and has similar color with cement. Besides, coal bottom ash (CBA) has pozzolanic activity which is attributed to the presence of $\mathrm{SiO}_{2}$ and $\mathrm{Al}_{2} \mathrm{O}_{3}$. Its reacts with calcium hydroxide $\mathrm{Ca}(\mathrm{OH})_{2}$ during cement hydration, to form additional Calcium Silicate Hydrate (CSH) and Cacium Aluminate Hydrate $(\mathrm{CAH})$. Therefore with additional Calcium Silicate Hydrate $(\mathrm{CSH})$ and Cacium Aluminate Hydrate $(\mathrm{CAH})$ are essential in forming denser matrix most important to better strength [16].

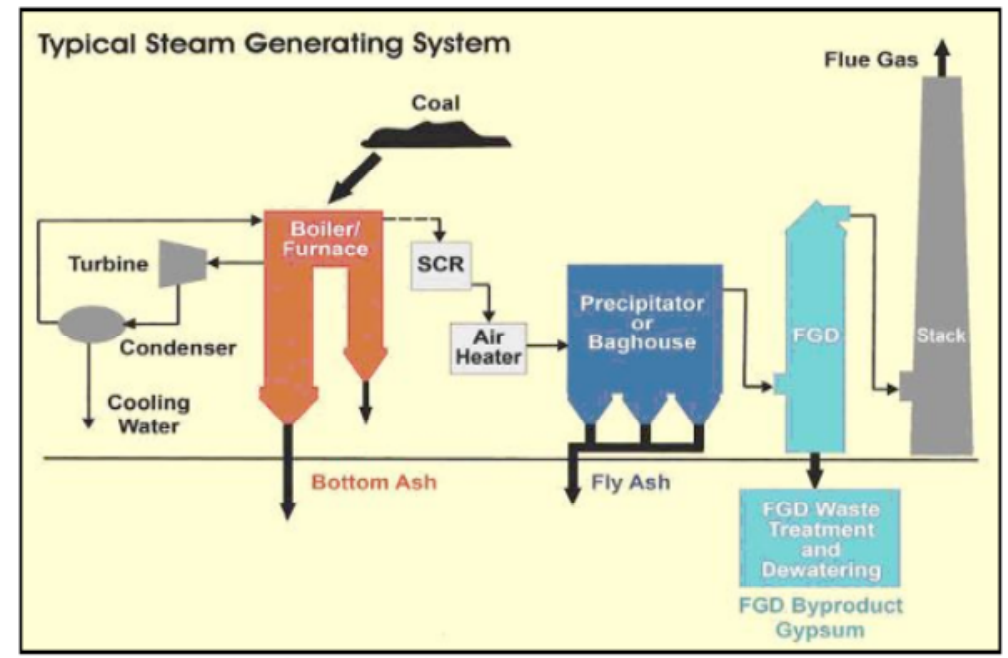

Fig. 1. Power plant that generate CBA (15) 


\section{Properties of grinded coal bottom ash}

\subsection{Chemical properties}

The chemical analysis of CBA by using X-ray fluorescence (XRF) will reveal that the main chemical compounds include Silicates $\left(\mathrm{SiO}_{3}\right)$, Aluminates $\left(\mathrm{Al}_{2} \mathrm{O}_{3}\right)$ and Iron oxide $\left(\mathrm{Fe}_{2} \mathrm{O}_{3}\right)$ with small amounts of calcium $(\mathrm{Ca})$, magnesium $(\mathrm{Mg})$, and sulfate $\left(\mathrm{SO}_{3}\right)$. Table 1 shows the XRF of Ordinary Portland cement, sieve coal bottom ash and grinded CBA. The work of Kim et al. [17] and Jaturapitakkul [18] showed that the sum main chemical that contain in $\mathrm{CBA}, \mathrm{SiO}_{2}+\mathrm{Al}_{2} \mathrm{O}_{3}+\mathrm{Fe}_{2} \mathrm{O}_{3}$ were exceeds $70 \%$ respectively. According to Standard Specification for Coal Fly Ash and Raw or Calcined Natural Pozzolan for Use in Concrete (ASTM C 618) for chemical composition grinded CBAes can be classified as Class F fly ash when the sum of silicates $\left(\mathrm{SiO}_{3}\right)$, aluminates $\left(\mathrm{Al}_{2} \mathrm{O}_{3}\right)$ and iron oxide $\left(\mathrm{Fe}_{2} \mathrm{O}_{3}\right)$ are exceed $70 \%$ [12]. The work Kim et al. [19] shows comparison result between sieved CBA and grinded CBA. The tabled shows that carbon content of grinded CBA is higher than sieve CBA. According to Jaturapitakkul [18] have notice an increase in pozzolanic activity with grinding of CBA. In their studied the variation in silica composition as different grinds time which indicates that the silica percentage is increased marginally after grinding [18].

\subsection{Particle shape}

Fig. 1 shows the SEM photographs of OPC, raw CBA and grinded CBA. The particle shape of Portland cement (Fig. 2(a)) is solid and irregular [21] while according to [18] observation on the raw CBA (Fig. 2(b)) shows that raw CBA is enormous,random shape, and high void. Thus, those materials with are preferred in construct roadway base and as course aggregate replacement under road base course [22]. Bajare et al. [9] states that the problem related to its particles size can be solved when grinding CBA. Besides, in their study also found that pozzolanic activity of CBA increases as the specific surface area increase. In addition, Bajare et al. [9] in their SEM report on 4 minute and 15 minute grinded CBA as in (Fig. 2(c, d)) can be observed that it is texture and shape similarity with the OPC photographs. Cheriaf et al. [23] conclude in their study that the small particles of grinded CBA can decrease the pore. Thus, it can give improvement in the strength of concrete.

\subsection{Particle Size Distribution}

Reported by Jaturapitakkul et al. [18] is tabulated in Table 3 show that the percentage amount of particles retained on sieve $325(45 \mathrm{~mm})$. According to ASTM 618, the allowance for fly ash is less than $34 \%$ retained on sieve 325 . As shown in table 3 , the percentage of grinded CBA and Portland cement type 1 are less than $34 \%$, while raw CBA result in percentage $94.5 \%$ which is more than $34 \%$ as allowance in ASTM 618. Hence, the major raw CBA particle is course. Based on the fact from [24], CBA greater than $5 \mathrm{~mm}$ in size suitable for coarse aggregate and less than $5 \mathrm{~mm}$ can be replace as a fine aggregate. Therefore, the raw CBA unclassified to be as fly ash as in ASTM 618 and the results also suggest that the raw CBA in experimental by [25] not suitable to be used as a pozzolanic material.

From all the results, it can be observed that the particle size distribution are descrease with increase in grinding duration, hence a positive effect was shown in terms of concrete density, as well as improvement in concrete properties. 
Table 1. Chemical composition of CBA

\begin{tabular}{|c|c|c|c|c|c|}
\hline Property & $\begin{array}{c}\text { Nagaratnamn } \\
\text { et al. [20] }\end{array}$ & Kim et al. [19] & $\begin{array}{c}\text { Kim et al. } \\
\text { [19] }\end{array}$ & $\begin{array}{c}\text { Jaturapitakkul } \\
\text { et al. [18] }\end{array}$ & $\begin{array}{c}\text { Jaturapitakkul } \\
\text { et al. [18] }\end{array}$ \\
\hline & OPC & Sieved CBA & Grinded CBA & Raw CBA & Grinded CBA \\
\hline $\mathrm{SiO}_{2}$ & 20.62 & 45.74 & 45.37 & 46.02 & 48.12 \\
\hline $\mathrm{Al}_{2} \mathrm{O}_{3}$ & 5.22 & 25.33 & 25.12 & 22.31 & 10.64 \\
\hline $\mathrm{Fe}_{2} \mathrm{O}_{3}$ & 3.60 & 6.86 & 5.81 & 10.64 & 10.55 \\
\hline $\mathrm{CaO}$ & 64.99 & 0.99 & 1.07 & 11.48 & 11.65 \\
\hline $\mathrm{K}_{2} \mathrm{O}$ & - & 3.71 & 3.87 & 3.47 & 3.45 \\
\hline $\mathrm{TiO}_{2}$ & - & 3.03 & 2.84 & - & - \\
\hline $\mathrm{MgO}$ & 0.07 & 1.25 & 1.16 & 3.47 & 3.45 \\
\hline $\mathrm{Na}_{2} \mathrm{O}$ & 0.50 & 0.70 & 0.64 & 0.07 & 0.07 \\
\hline $\mathrm{SO}_{3}$ & - & - & - & 1.52 & 1.76 \\
\hline
\end{tabular}

Table 2. Physical properties of Portland cement, original CBA and Ground CBA (18)

\begin{tabular}{|c|c|}
\hline Sample & Retained on Sieve 325 (\%) \\
\hline Portland cement type 1 & 4.8 \\
\hline Original CBA & 94.5 \\
\hline Grinded bottom ash & 2.8 \\
\hline
\end{tabular}

Table 3. Physical proprties of portland cement, original CBA and Ground CBA

\begin{tabular}{|c|c|c|c|c|c|c|c|}
\hline Sample & $\begin{array}{c}\text { Portland } \\
\text { cement } \\
\text { type 1 }\end{array}$ & $\begin{array}{c}\text { Original } \\
\text { CBA }\end{array}$ & $\mathbf{1}$ hour & $\mathbf{2}$ hour & $\mathbf{3}$ hour & $\mathbf{4}$ hour & 6 hour \\
\hline $\begin{array}{c}\text { Specific } \\
\text { gravity }\end{array}$ & 3.14 & 2.00 & 2.02 & 2.11 & 2.14 & 2.21 & 2.25 \\
\hline
\end{tabular}

\subsection{Specific Gravity}

To enhance the performance of CBA Cheriaf et al. [23] in their study conduct ground in a ball mill for 1-6 hour. As shown in Table 4, as grinding time extend to 6 hour, the reading of specific gravity increment from grind at time 1 hour to 6 hour grinding time. The same phenomenon was observed by Payá et al. [26] when grinding fly ash. They concluded that it was due to crushing porous carbon particles. A study by Jaturapitakkul et al. [18] reports that specific gravity of portland cement measured by the pycnometer method was 3.14 while raw CBA was 2.00. Jaturapitakkul et al. [18] concluded in their study that reducing size of bottom ash by different grinding time give better result in microstructure and improve pozzolanic activity.

\section{Properties of hardened coal bottom ash concrete}

Since the CBA with different grinding time has different properties than normal CBA, it behaves differently in concrete mixes and causes the concrete with replacement CBA to perform different for different grinding time. The properties of CBA on concrete with different grinding time are shown below. 


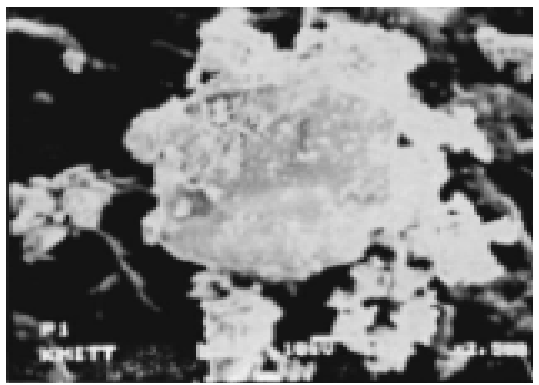

a) Portland Cement [21]

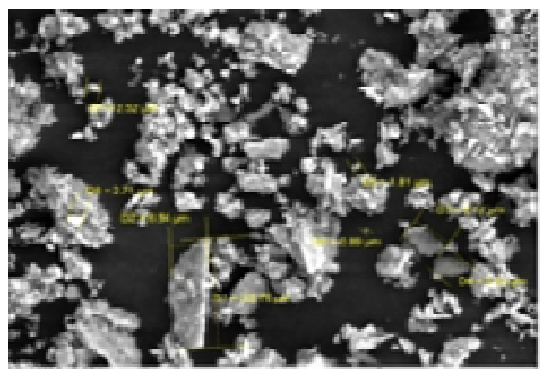

c) 15-min grinding $\mathrm{CBA}[9]$

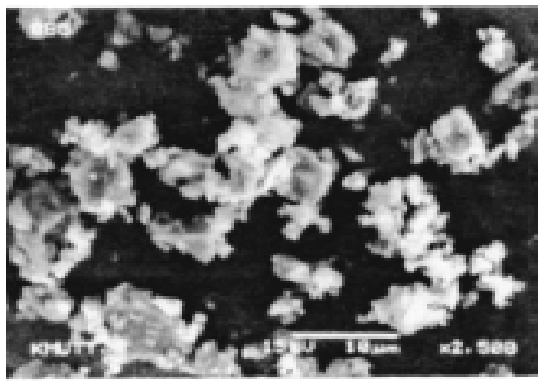

e) retained on Sieve 325 is less than $5 \%$ by weight [9]

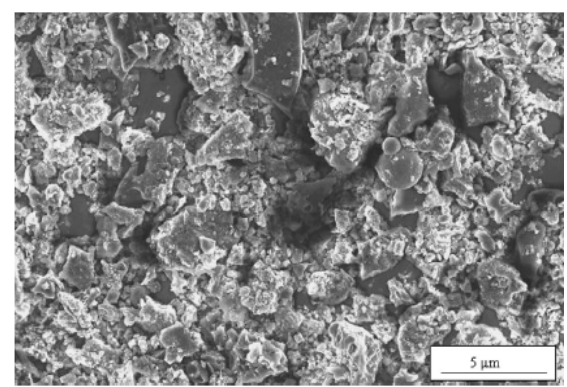

b) Raw CBA [18]

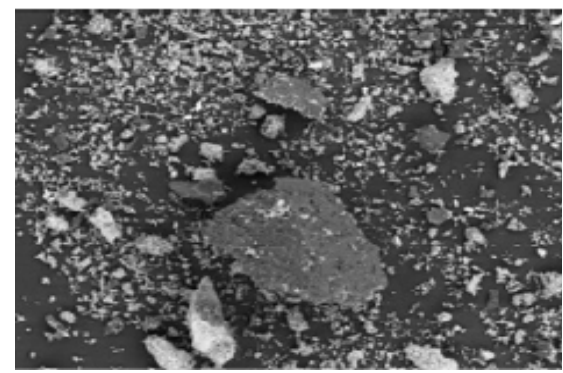

d) 4-min grinding $\mathrm{CBA}[9]$

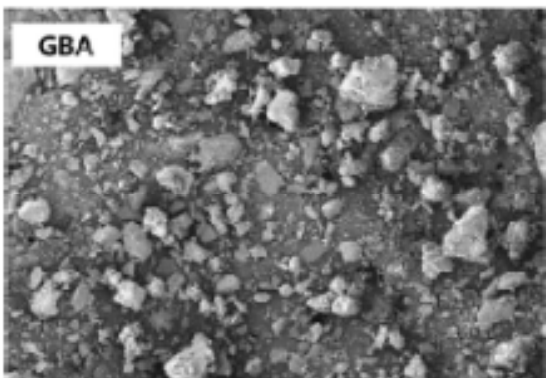

f) 30-min grinding $\mathrm{CBA}[22]$

Fig. 2. Scanning electron micrograph of grinded CBA

\subsection{Microstructure}

Scanning Electron Microscopy (SEM) was conducted by a few researches to analyze the microstructure. According to Siddique et al. [27] it is well known that, the calcium-silicatehydrate $(\mathrm{CSH})$ is major present. According to work by Whittaker et al. [28] shown in the SEM images as in Fig. 3(b) their replacement of ordinary portland cement with grinded CBA resulted in an increase in the porosity of the structure. Therefore, in their experimental result conclude that the porosity of the hardened structures may result to a higher water demand. As observe by Singh et al. [29] there were formation of CSH gel in mixture.

As observed by Cheriaf et al. [23] the SEM show a slaglike morphology as shown in Fig. 3. Most of slaglike morphology of grinded CBA unreacted by calcium hydroxide. The grinded CBA was grind in a grinding machine for 6 hour. At up to 28 days, $\mathrm{Ca}(\mathrm{OH})_{2}$ began to be work with the particle in concrete, the reaction lead to the formation of CSH gel and needles as in Fig. 3. 


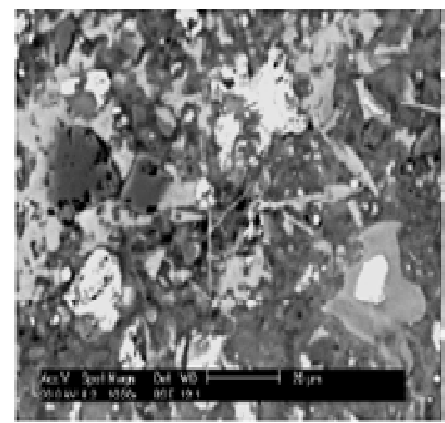

(a) OPC

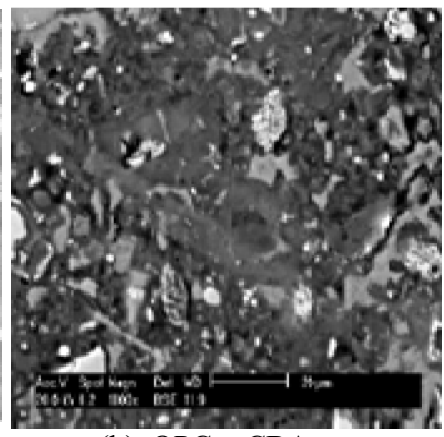

(b) $\mathrm{OPC}+\mathrm{CBA}$

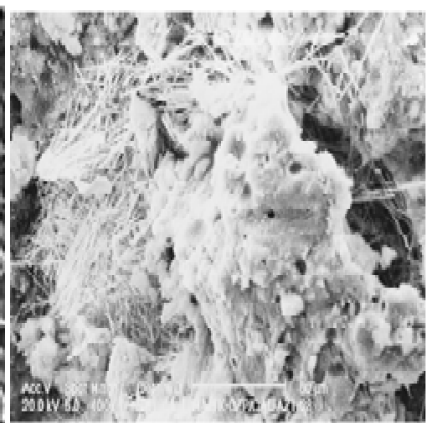

(c) $\mathrm{OPC}+$ grinded $\mathrm{CBA}$

Fig. 3. Image of grinded CBA

\subsection{Compressive strength}

Compressive strength of CBA is influenced by the grinding time of CBA by high ball mill. Most research recommended that, the grinded CBA has a potential to be a good pozzolanic material by increase in fineness.

According to Kurama et al. [30] the reactive calcium silica in ash will react with lime will form calcium silicate and aluminates hydrates. These hydrates will fill the voids and eliminate lime in concrete. Thus, this will reducing the permeability and enhances the strength of concrete. According to their experimental results, compressive strength increase as amount of grinded CBA replacement up to $10 \%$. At 56 day, about $5 \%$ increases in compressive strength compare to the control mixture. Therefore, addition of grinded CBA as cement replacement could gain the requirement properties such pozzolanic, thus improve the strength and durability of concrete.

Differently with the work result by Kim et al. [17], the higher the replacement grinded CBA percentage resulted in lower compressive strength. As shown in table, the result of compressive strength of grinded CBA for 3, 28 and 91 day was replaced with cement in percentage replacement of $15 \%$ and $30 \%$. The control cube was obtaining $79 \mathrm{MPa}$ for compressive strength test higher than grinded CBA, 34 and $38 \mathrm{MPa}$ respectively for $15 \%$ and 30\% replacement levels. The control cube had strength higher than 15 and $30 \%$ replacement grinded CBA cube. As observed in Ghafoori et al. [31], due to the angular shape of grinded CBA give an effect on the amount of water and the result of compressive strength at initial curing. At the end 60 days curing, there are $7 \%$ increase in strength was recorded and $13.7 \%$ increase in strength at 90 day curing.

Bajare et al. [9], CBA with grinding time 15 minutes is $31 \mathrm{MPa}$ higher than $27 \mathrm{MPa}$ from CBA grinded at 240 seconds. Jaturapitakkul et al. [18] found similar behavior with tests using $20 \%$ replacement of ground bottom ash that performed as well as control. The result of compressive strength at 28 days was $37.1 \mathrm{MPa}$ or $97 \%$ of the control concrete. This study use grinded CBA which passin

g on Sieve 325 more than $95 \%$. The compressive strength with $20 \%$ replacement CBA increase from 36.6 to $37.1 \mathrm{MPa}$ due to $\mathrm{CBA}$ exhibited good pozzolanic after being ground to smaller particle.

Canpolat et al. [32] observed that there poor performance the replacement of cement with bottom ash at initial curing. At the age of 7 days, there was a continuing improvement in the performance of the mixtures. When curing was extended to 28 days, a dramatic increase in the performance of the mixtures was noticed. Most of the compressive strength values of all the cement mixes are higher than control sample. 


\section{Discussion and conclusion}

This paper was prepared by reviewing the different on grinding time of CBA and the effect on concrete in terms of compressive strength. From the review, the properties of concrete containing CBA were improved by decreasing the particle size of CBA. Furthermore, SEM analysis shows that the texture of the cement paste containing CBA with different grinding time was denser and compact compare with raw CBA. Generally, pozzolanic reaction of CBA was directly related to its fineness. Thus, the fineness of CBA is increased with increased in grinding time. From the literature review, by increasing the fineness of CBA in concrete mixture helps to achieve denser and more impermeable cement matrix.

\section{References}

[1] S.A. Kallen, Burj Khalifa, The Tallest Tower in the World, Norwood House Press, Chicago, (2014)

[2] A.M. Neville and J.J. Brooks, Concrete Technology, Pearson Education Limited, Harlow, England, (2003)

[3] P.K. Mehta and P.J.M. Monteiro, Concrete, Structure, Properties and Materials, Prentice Hall, New York, (1993)

[4] N. Md Noor, Physical Performance and Durability Evaluation of Rubberized Concrete, Physical Performance and Durability, Doctor of Engineering, Kyushu University, Fukuoka, (2014)

[5] S. Adekunle, S.Ahmad, M. Maslehuddin and H.J. Al-Gahtani, Properties of SCC prepared using natural pozzolana and industrial wastes as mineral fillers, Cement and Concrete Composites, 62, 125-133 (2015)

[6] A.U. Abubakar and K.S. Baharudin, Potential use of Malaysian thermal power plants, 3(2), 25-37 (2012)

[7] N. Jamaluddin, A.F. Hamzah and M.H.Wan Ibrahim, Fresh properties and flexural strength of SCC CBA, 1-6 (2016)

[8] S. Shahidan, Properties of concrete with difference percentage of the RHA as partial cement replacement, Material Science Forum, 803, 288-293 (2014)

[9] D. Bajare, G. Bumanis and L. Upeniece, CCBA as microfiller with pozzolanic properties for traditional concrete, Procedia Engineering, 57, 149-158 (2013)

[10]A.R. Awang, A. Marto and A.M. Makhtar, Advane science influene technology morphological and strength properties of Tanjung Bin coal ash mixtures for applied in geotechnical engineering work, 55-62, (2012)

[11]N.E. Zainal Abidin, M.H. Wan Ibrahim, N. Jamaluddin, K. Kamaruddin and A.F. Hamzah, The effect of bottom ash on fresh characteristic, compressive strength and water absorption of self-compacting concrete, Applied Mechanics and Materials, 660, 145-151 (2014)

[12]C.S. Pei, Coal as an energy resource in Malaysia, 399-410 (1993)

[13]A. Farhana and B. Jamaludin, Energy Mix and Alternatives Energy for Sustainable Development in Malaysia, Uiversiti Putra Malaysia, 1-9 (2001)

[14] M.S.H. Mohd Sani, F. Muftah and Z. Muda, The prop of special concrete using washed bottom ash (WBA) as partial sand replacement, Int. J. of Sustainable Construction Engineering and Technology, 1(2), 65-76 (2010)

[15]A.U. Abubakar, K.S. Baharudin and T. Infrastructure, Properties of concrete using Tanjung Bin Power, 3(2), 56-69 (2012)

[16]P. Filipponi, A. Polettini, R. Pomi and P. Sirini, Physical and mechanical properties of cement-based products containing incineration bottom ash, Waste Management, 23(2), $145-56(2003)$ 
[17]H.K. Kim and H.K. Lee, Use of power plant bottom ash as fine and coarse aggregates in high-strength concrete, Construction and Building Materials, 25(2), 1115-1122 (2011)

[18]C. Jaturapitakkul and R. Cheerarot, Development of bottom ash as pozzolanic material, 0899-1561, 48-53 (2003)

[19]H.K. Kim, Utilization of sieved and ground coal bottom ash powders as a coarse binder in high-strength mortar to improve workability, Construction and Building Materials, 91, 57-64 (2015)

[20]B.H. Nagaratnam, M.E. Rahman, A.K. Mirasa, M.A. Mannan and S.O Lame, Workability and heat of hydration of self-compacting concrete incorporating agroindustrial waste, J. of Cleaner Production, 112, 882-894 (2016)

[21]Z. Zhang, B. Zhang, and P. Yan, Comparative study of effect of raw and densified silica fume in the paste, mortar and concrete, Construction and Building Materials, 105, 82-93 (2016)

[22] M.H. Wan Ibrahim, A.F. Hamzah, N.Jamaluddin, R. Putrajaya and M.F. Arsha, Split tensile strength on self-compacting concrete containing coal bottom ash, Procedia Social and Behavioral Sciences, 195, 2280-2289 (2015)

[23] M. Cheriaf, J. Cavalcante and J. Pera , Pozzolanic properties of pulverized CCBA, Cement and Concrete Research, 29, 1387-1391 (1999)

[24]R. Siddique, Utilization of coal combustion by-products in sustainable construction material resources, Conservation and Recycling, 54(12), 1060-1066 (2010)

[25]A. Abdul Kadir and M.I. Hakeem, An overview of fly ash and bottom ash replacement in SCC, Advanced Materials Engineering and Technology, Bandung, (2013)

[26] J. Paya, J. Monzo, M.V. Borrachero and E. Peris-Mora, Mechanical treatment of fly ashes, Part I: Physical-chemical characterization of ground fly ashes, Cement and Concrete Research, 25(7), 1469-1479 (1995)

[27]R. Siddique, P. Aggarwal and Y. Aggarwal, Influence of water/powder ratio on strength properties of self-compacting concrete containing coal fly ash and bottom ash, Construction and Building Materials, 29, 73-81 (2012)

[28] M. Whittaker, R. Taylor, Q. Li, S. Li, The effect of bottom ash as a partial cement replacement

[29] M. Singh and R. Siddique, Effect of coal bottom ash as partial replacement of sand on workability and strength properties of concrete, J. of Cleaner Production, 112, 620-630 (2016)

[30]H. Kurama and M. Kaya, Usage of coal combustion bottom ash in concrete mixture, Construction and Building Materials, 22, 1922-1928 (2008)

[31]N. Ghafoori and J. Bucholc, Investigation of lignite-based bottom ash for structural Concrete, J. Materials in civil Engineering, 8, 128-137 (1996)

[32]F. Canpolat, K. Y lmaz, M. M. Kose, M. Sumer and M. A. Yurdusev, Use of zeolite, coal bottom ash and fly ash as replacement materials in cement production, Cement and Concrete Research, 34, 731-735 (2004) 